The Synod commenced the revision stage of the draft Clergy Discipline Measure (formerly entitled the Ecclesiastical Jurisdiction (Discipline) Measure) (see 5 Ecc LJ 382) but, because of the volume of liturgical business, debate was adjourned at clause 7. It is hoped that the revision stage will be completed at the July Group of Sessions. The main changes to the Measure made by the Revision Committee include inserting as a clause of the Measure matters relating to the standard of proof, to the requirement for a public hearing and to the decision of the tribunal. On the question of the composition of the tribunal, it was concluded that it should be made up of three members. The Committee was conscious that having more members would increase the costs and make it more difficult to agree dates; the strength of secular precedents (such as magistrates' courts and industrial tribunals) were also noted. The Committee also decided that cases before the tribunal should be decided by majority rather than that the members should be unanimous: this was considered to be appropriate given the fact that the Measure was establishing a disciplinary procedure, not a criminal one.

The Revision Committee for the draft Synodical Government (Amendment) Measure (see 5 Ecc LJ 383) had also completed its work and had tabled its report for revision in full Synod. However, as with the Clergy Discipline Measure, there was insufficient time to debate it, and the revision stage had to be held over until the July Group of Sessions, a report of which will appear in the next issue of this Journal.

The July Sessions are the last of the quinquennium. Fresh elections to the Convocations and to the House of Laity will be held in the period between July and October, and the new Synod will be inaugurated by the Queen on 14th November in Westminster Abbey.

\title{
THE GENERAL SYNOD OF THE SCOTTISH EPISCOPAL CHURCH
}

\author{
IVOR GUILD \\ Writer to the Signet
}

Out of the usual menu of canons and financial measures at the Synod in 2000 the most popular choices were the Canon of the Election of Bishops, a paper (massive and meaty) by the Clergy Personnel Commission and, for emotional content, the possibility of female bishops. This last was quickly disposed of by the appointment of a committee to produce a Green Paper for next year's Synod, though not before those who oppose female priests had argued for delay (possibly to the next millennium) on the ground that matters were proceeding too fast.

The Canon of Election of Bishops (Canon 4) came up for second reading. No canon has been the subject of more amendments in the past, but the version now proposed seeks to inject into the procedure a provincial element on the ground that the appointment of a bishop creates ripples far beyond his own diocese. Dioceses, however, are jealous of their perceived right to select the person who will hold sway over them, and in this new canon the last word remains in local hands.

On a vacancy occurring a Preparatory Committee will be set up under the convenership of the Primus, consisting of five members of the Provincial Panel (a new body made up of one lay person and one cleric from each diocese), a bishop, and two further lay and clerical members chosen by the diocesan synod of the diocese which is vacant. With the aid of a Description of the Diocese compiled by the Diocesan Synod (which is to contain the relevant future plans and intentions for the work of 
the diocese so as to enable the qualities to be looked for in the bishop to be identified), the Preparatory Committee has to submit the names of not less than three nor more than five candidates to the Electoral Synod. Any person may suggest names for consideration by the Committee, but the Bishops may veto a name before the short list is made up for submission. Since the Electoral Synod is made up of one lay representative from every charge in the vacant diocese and all clergy instituted to a cure of souls along with every clergyman living in the diocese who holds a formal licence for a definite sphere of duty involving regular pastoral work, the final selection remains a local matter. To be elected a candidate still requires a majority vote in each of the lay and clerical houses. A new provision, however, is the possibility of an elector writing 'none' on his voting slip, and, if the number of such slips exceeds one third of the total votes case, the election is to be held void.

The new procedure will result in a candidate being initially interviewed by the Preparatory Committee, submitting a curriculum vitae, and answering a questionnaire formulated by the Committee. Later he will face the Electoral Synod, by whom he will be invited to present a brief account of his views on the future of the diocese and the role of the bishop. He may also have to respond to written questions from members of the Synod.

The whole process is subject to a tight time schedule and elaborate rules. How well it will operate will be tested later this year, as the Bishop of Edinburgh retires at the end of October, and the new Canon will apply to the election of his successor. The Canon, however, does not govern the appointment of Primus, the holder of that office being selected by the bishops from among their own number at a meeting of the Episcopal Synod on 1 st November.

Other canonical changes were mainly of a tidying-up nature. Passed at a second reading was the creation of Diocesan Building Advisory Committees. With the current freedom from the requirement of listed building consent for alterations to church buildings it was felt that a more responsible attitude and proper regulation by the Church were necessary if the planning authorities were to allow this freedom to continue. With the setting up of these committees authorisation will be needed from them before any alterations are made to a building or its contents a procedure which brings the Scottish Church more in line with faculties in England. The previous discretion of vestry and rector is thus restricted, with a right of appeal open to those dissatisfied. Resolutions were also passed dealing with such matters as experimental reordering of ecclesiastical ornaments and furniture, and regulating applications, advertisement and appeals.

The only canonical change presented for the first time proposed that the membership of the General Synod be increased by the addition of 'a person elected to represent the Scottish Church on the Anglican Consultative Council'; it was passed without opposition.

The working party on human sexuality submitted a short report which did little more than promise to offer the Church a discussion document by Lent 2001 . The second Interim Report on Scottish Church Initiative for Union was rather more lengthy. It identified the issues which required to be settled, and reflected on the nature and purpose of the Church and the kind of Church which would best serve the people of Scotland. It gave a broad definition to the meaning of mission (mission is the good news of God's love incarnated in the witness of a community for the sake of the world) before tackling leadership issues of eldership, parity of ministry, and episcope. Finally it sought to work out the proper relationship with other Churches and how union might affect other Church traditions.

Socially responsible investment is a subject which has been discussed over a number of years. The policy put forward by the Diocese of Glasgow was accepted. Under it the Church should not invest in companies whose main businesses were 
armaments, pornography or tobacco, 'main' being defined as more than fifteen per cent of turnover.

The Clergy Personnel Commission was set up in 1997. The various recommendations in its Report were voted on in batches and little discussion took place. The abolition of child allowances caused some distress, and the much debated question of whether tied rectories should be retained or rent allowances given in lieu remained unresolved. The recommendations dealt with such mundane subjects as expenses, motoring costs, pensions, sick pay, sabbaticals and retirement age. It was agreed that paternity leave should be given. Many of the matters arise because of the ambivalent position of the clergy who for some purposes are regarded as employed and for others as self-employed. Much of this is of historical origin, and many would consider that the position should be rationalised; that clergy should operate under an appropriate contract of employment which would set out their rights, but at the same time give the bishop and congregation some method of dealing with those who are manifestly failing in their ministry.

Altogether this was a quiet and uncontentious Synod, which rubber-stamped the hard work done by committees throughout the year. It was a farewell to Bishop Holloway with uncertainty about the direction in which his successor would lead the Scottish Church.

\section{RESIDENTIAL CONFERENCE}

\section{RELIGIOUS LIBERTY AND HUMAN RIGHTS \\ TRINITY HALL, CAMBRIDGE 30th MARCH-1st APRIL 2001}

The Human Rights Act 1998 will come into force on 2nd October 2000 making the provisions of the European Convention on Human Rights directly applicable in English courts. Accordingly, the Ecclesiastical Law Society will be devoting its first residential conference of the new millennium to the subject of Religious Liberty and Human Rights. Speakers will include:

Sir Stephen Sedley, Lord Justice of Appeal

Professor Simon Lee, Rector of Liverpool Hope University College, author of Judging Judges and Believing Bishops

Mr Mark Chopko, General Counsel of the United States Catholic Conference. Washington DC and Fellow in the International Academy of Freedom of Religion and Belief

Professor Ian Leigh, University of Durham, author of Law; Politics and Local Democracy

Professor Javier Martinez-Torron, University of Granada, author of AngloAmerican Lai' and Canon Law

Professor Nicholas Sagovsky, William Leech Professorial Research Fellow in Applied Christian Theology, University of Newcastle

The preacher at the conference Eucharist will be the Right Reverend John Gladwin. Bishop of Guildford.

A booking form is enclosed with this issue; please complete and return it as soon as possible to ensure a place. 